\title{
TRAUMATIC LUMBAR ESPONDYLOLISTHESIS: A CASE REPORT
}

\author{
ESPONDILOLISTESIS LUMBAR TRAUMÁTICA: UN INFORME DE CASO \\ ESPONDILOLISTESE LOMBAR TRAUMÁTICA: UM RELATO DE CASO
}

Enrique Vargas Uribe , José Luis González Gallegos', Leonardo Gutiérrez Ramírez ${ }^{1}$

\begin{abstract}
We present a case of traumatic espondylolisthesis L5 S1 A0 53 B3.3 ASIA B in a young patient after a high energy car accident. This entity is a rare injury that requires immediate attention. Treatment should be prompt in order to provide the best prognosis since this is an unstable and severe lesion that presents with neurological deficit in half of the patients. Computed tomography and magnetic resonance imaging have shown to be extremely valuable for the diagnosis and are mandatory for this kind of injuries. In this case it is noteworthy that the intervertebral disk was intact. It is reported that if surgery is performed 24 to 48 hours after the accident, the improvement of neurological deficit is very feasible. In this case posterolateral fusion with autologous bone graft and multiplanar transpedicular posterior instrumentation and decompression were performed 52 hours after the accident. The patient presents one year after surgery with improvement in movement and sphincter control and with radiographic evidence of a complete fusion.
\end{abstract}

Keyword: Espondylolisthesis; Spinal fractures; Intervertebral disc; Case reports.

RESUMO

Apresentamos um caso de espondilolistese traumática L5 S1 A0 53 B3.3 ASIA B em paciente jovem, após acidente de carro de alta energia. Essa entidade é uma lesão rara, que exige atenção imediata. O tratamento deve ser rápido, a fim de proporcionar o melhor prognóstico, uma vez que é uma lesão instável e grave que se apresenta com déficit neurológico em metade dos pacientes. A tomografia computadorizada e a ressonância magnética foram extremamente valiosas para o diagnóstico e são obrigatórias para esse tipo de lesão. Neste caso, deve-se salientar que o disco intervertebral estava intacto. Relata-se que se a cirurgia for realizada de 24 a 48 horas após o acidente, a melhora do déficit neurológico é bastante viável. Neste caso a fusão posterolateral com enxerto ósseo autólogo e instrumentação multiplanar posterior transpedicular, assim como a descompressão foram realizadas 52 horas após o acidente. O paciente apresenta-se um ano após a cirurgia com melhora motora e controle esfincteriano, além de evidências radiográficas de fusão completa.

Descritores: Espondilolistese; Fraturas da coluna vertebral; Disco intervertebral; Relatos de casos.

RESUMEN

Presentamos un caso de espondilolistesis traumática L5 S1 AO 53 B3.3 ASIA B en un paciente joven tras un accidente de alta energía en automóvil. Es una lesión rara que requiere atención médica inmediata. El tratamiento debe ser lo más rápido posible para mejorar el pronóstico ya es una lesión inestable y severa que se presenta con déficit neurológico en la mitad de los pacientes. La tomografía compuarizada y la resonancia magnética son obligatorias en estos casos pues han demostrado ser invaluables para el diagnóstico y manejo. En este caso hay que destacar que el disco intervertebral estaba intacto. Se ha informado de que si la cirugía se lleva a cabo 24 a 48 horas después del accidente, la mejora del déficit neurológico es muy probable. En este caso se realizaron la fusión posterolateral con injerto óseo autólogo e instrumentación multiplanar transpedicular posterior, así como una descompresión del segmento, 52 horas después del accidente. El paciente se presenta un año después de la cirugía con mejoría motora y de control de los esfínteres además de evidencia radiográfica que demuestra fusión completa.

Descriptores: Espondilolistesis; Fracturas de la columna vertebral; Disco intervertebral; Informes de casos.

\section{INTRODUCTION}

Traumatic espondylolisthesis are rare injury, all resulting from high-energy mechanisms, most of them after an anterior direction trauma. Type B injuries of the AO classification, appear after hyperextension or flexion distraction forces. ${ }^{1}$ Of these, the posterior dislocation, included in the classification as B3.3, is presented less frequently according to the study by Magerl et al. ${ }^{2}$ reporting a prevalence of $0.021 \%$ based on an analysis of 1445 cases.

This injury is highly unstable and implies a severe damage to the ligaments and intervertebral discs, most importantly, it has a high frequency of neurological deficits, reported as high as $50 \%$.

Neurologic dysfunction is documented accurately in this case, following the protocol of the American Spinal Injury Association, wich has become the standard for the neurologic evaluation of any spine trauma at our institution and others. ${ }^{5}$

We report a patient with a posterior fracture-dislocation L5S1 AO 53B3.3 (Figure 1) after a car accident presenting with severe neurological damage, the patient was acquainted about the collected information and that it could be used for future publication.

\section{Case report}

Our patient is a 17 years old male with no relevant personal medical history, family history of cardiopathy (deceased maternal grandfather after acute myocardial infarction), no family history of neoplastic diseases, biweekly consumption of alcohol reaching intoxication and occasional use of marijuana, Denies any active disease

1. Servicio de Columna del Centro Médico Nacional de Occidente, Instituto Mexicano del Seguro Social, Guadalajara, Jalisco, México.

Study conducted at Centro Médico Nacional de Occidente, Instituto Mexicano del Seguro Social, Guadalajara, Jalisco, México.

Correspondence: Av. Empresarios no.150 piso 23, Cidade: Zapopan, Jalisco, México Caixa Postal: 45116. evargas.u@gmail.com 


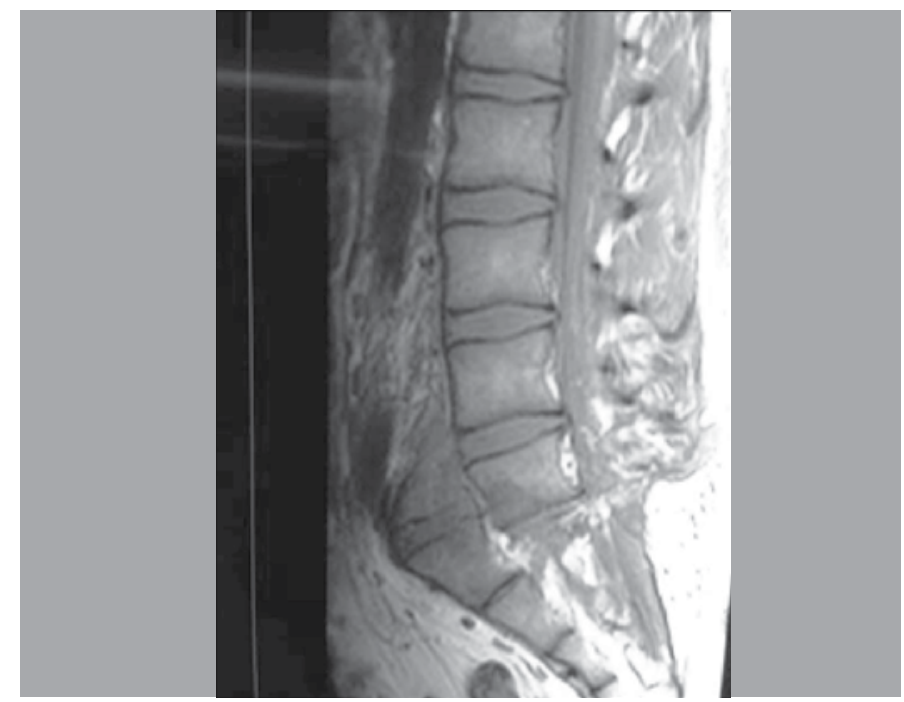

Figure 1. MRI were the dislocation of L5S1 is evident and the integrity of the intervertebral disks is noted.

tonsillectomy at the age of 9 years, he denies trauma and fracture history. Hemotype $\mathrm{O}+$, no history of blood transfusions.

He was involved in a high speed car accident, he was traveling as a passenger in the back seat of a pick-up truck without seat belt and was trapped under the truck suffering loss of consciousness for aproximately 30 minutes, denies vomiting and seizures. He is assisted by paramedics who apply primary care measures, he is then taken by ambulance to the nearest care facility and 2 hours after he is transfered to a specialty hospital in wich the diagnosis of lumbosacral spondyloptosis and right hemopneumothorax was made, a chest tube for the management of hemopneumothorax was placed and NASCIS II scheme was applied with an initial bolus of methylprednisolone $30 \mathrm{mg} / \mathrm{Kg}$, followed by an infusion at $5.4 \mathrm{mg} /$ $\mathrm{Kg} / \mathrm{hr}$ for 23 hours, he arrives at our institution 3 hours after the accident for surgical treatment.

Upon arrival, he is confined to a stretcher with 15 points on Glasgow scale, presence of edema and erythema in the face, eyes with conjunctival hyperemia, isochoric pupils with intact reflexes and mobility, denies any visual disturbances, neck is painless, protected with philadelphia cervical collar wich was removed after failure to show any ligament or bone lesions on imaging studies, mobility complete and undisturbed, thorax had a chest tube through the fifth intercostal space on the right mid-axillary line draining serosanguineous material, aproximately $110 \mathrm{cc}$, with adequate ventilated lung fields and basal rales in right hemithorax without wheezing ; rhythmic precordium, good intensity, no added noises. Intact upper extremities, with complete mobility, muscle strength conserved $(5 / 5$ on the scale Daniels), without changes in sensitivity, flat abdomen, decreased peristalsis in number and intensity, soft, not tender to palpation superficial or deep, presence of lumbosacral pain of moderate intensity $(6 / 10)$.

Lower extremities are eutrophic, muscle strength 4/5 on knee flexors and hip extensors and 2/5 of hip extensors and knee flexors, on the scale of Daniels, muscle strength abolished $(0 / 5)$ for plantar flexion and extension of both feet, flexion and extension of toes, right ankle with swelling and bruising secondary to a non displaced fracture or the medial malleolus, altered sensitivity with paresthesias in dermatomes L4L5, hipoestesias S2S5, patellar reflex normal, achilles diminished, Babinski negative; bulbocavernous reflex and anal blink absent, with the presence of urethral foley catheter, draining clear urine. Therefore, a B on the ASIA Impairment Scale is provided, with sensory level S1 and motor level L5.

In simple radiographic studies, a lateral view of lumbosacral spine reported soft tissue edema, with adequate bone density and posterior spondylolisthesis L5S1 of $100 \%$ according to a grade IV on the Meyerding Scale.
In the anteroposterior radiographic view a slight proximal axial rotation to the right is reported, on the pelvis a non displaced fracture of the sactum is noted, transverse simple fracture of medial malleolus base is evident, coronal or sagittal displacement, without invading the tibiotalar joint, and with intact fibula, in tomographic imaging, reaffirms the above mentioned, without injury to the pedicle or facet joints, on MRI edema was noted in the soft tissue adjacent to the injury with L5S1 intervertebral disk without evidence of damage and disruption of the medullary cone at the same level is noted.

Hospitalization and admision to our unit was made $52 \mathrm{hrs}$ after the accident, and surgery is

scheduled for reduction of dislocation, dural exploration, posterolateral fusion and fixation with polyaxial screws on L5 and S1.

A difficult reduction is reported as well as transverse medullary cone injury with complete obliteration of the medullary canal and partial laceration of the dural sac wich was repaired with nylon stitches and dural protection gel, after the spine surgery, fixation of the medial malleolus is performed by placing interfragmentary compression screws, an surgery time of 3 hours and approximately $800 \mathrm{cc}$ of bleeding are reported.

In postoperative radiographic studies (Figure 2) we observe appropriate reduction of the listhesis, without loss of height in the intervertebral disk space and good placement of screws through the pedicles, with restoration of lordotic curvature and of the Ferguson angle.

ASIA reassesment 24 hours after surgery is reported with no changes, thorax surgeons extract the endopleural tube $48 \mathrm{hrs}$ after placement

The patient was discharged with instructions of passive and active joint movilization of extremities to prevent contractures and with Taylor corset for every day use, we prevent thromboembolic events with the application of low molecular weight heparins, we continue clinical and radiographic surveillance as an outpatient, at six months, the patient is able to walk but has an electromiography that reports permanent damage over the right ciatic nerve wich manifests as a drop foot, also hipoesthesia of right L5 and S1 dermatome is present, he recovered anal sphincter control, but not vesical, so a foley urethral catheter is permanently used, fusion is reported as complete by tomography.

Over the literature review we found that the highest incidence of this lesion is reported in patients who have undergone high-impact accidents, primarily car accidents, most of them with non or partially reversible neurologic injury.

Imaging studies, such as computed tomography and magnetic resonance imaging have shown to be extremely valuable for the diagnosis of bone and intervertebral disc injuries, and are mandatory. ${ }^{6}$

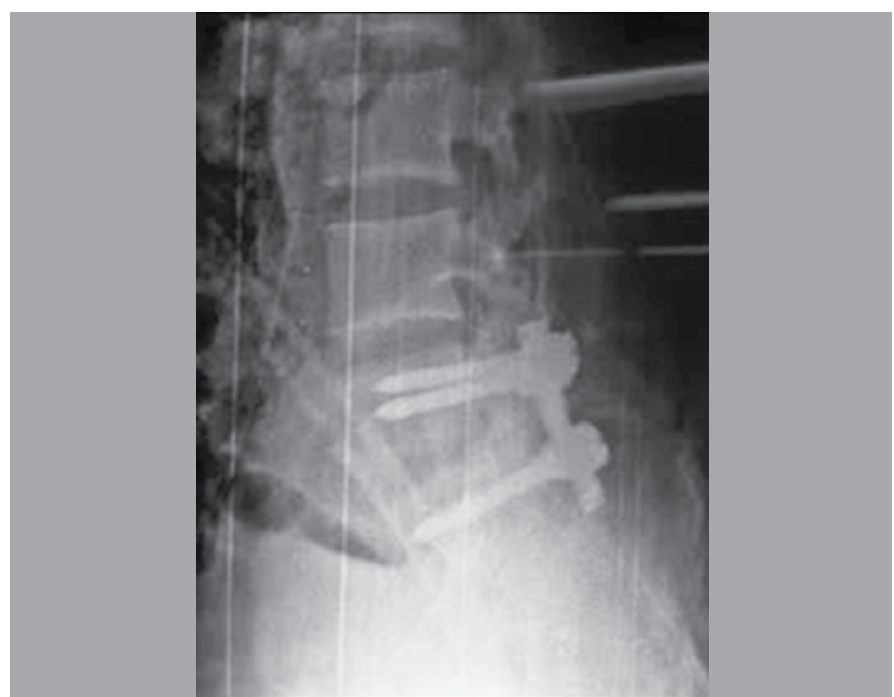

Figure 2. Postsurgical radiographic view were appropiate reduction is noted with adecuate placement of transpedicular screws. 
Plain radiographs remain useful to establish a snapshot of the deformity, as well as the outcome and follow-up, such injuries are usually treated with a two level instrumentation, reduction and posterolateral fusion to restore the normal relationship of the anotomy lost during trauma. ${ }^{7}$

On this case we decided as the best treatment option the reduction, posterolateral fusion with autologous graft and poliplanar transpedicular posterior instrumentation, wich is the technique suggested for this cases by most authors. ${ }^{1-3,8}$

We didnt find any disrruption of the intervertebral L5S1 disk, so no procedure was made at this level. $., 7,9,10$

We must take into account the time interval between trauma and surgery, in this case, we present a long duration dislocation so the reduction is expected to be difficult.

La Rosa reported an improvement of $89.7 \%$ in patients with incomplete neurological injury who were operated on within the first 24 hours compared with those operated later or when non surgical treatment was chosen. ${ }^{11}$

The main factors associated with recovery of neurological function are well described; early decompression and the degree of narrowing of the spinal canal being the most relevant. ${ }^{12,13}$
Carlson et al. reported in their study in dogs that the vascular supply in the medullary region is inversely proportional to the duration of the compression, with increasing risk of irreversible damage. ${ }^{14}$

We suggest that our patient was injured by a combined mechanism of hyperextension injury and shear forces, with the very uncommon finding of the absence of intervertebral disk displacement or disruption. We could criticize the delay in surgical treatment, wich should never surpass 48 hours, even more if damage to the medullary cone is present, as with this case.

Performing surgery within the first 48 hours after the accident may have facilitated the reduction with proper stabilization and decompression of neural elements, therefore limiting the perpetuation of mechanical and chemical adverse events.

As important as the goal of neurological recovery, the surgical treatment should also aim to the convenience of rapid mobilization and rehabilitation, thus avoiding complications related to prostration.

All authors declare no potential conflict of interest concerning this article.

\section{REFERENCES}

1. Fabris D, Costantini S, Nena U, Lo Scalzo V. Traumatic L5-S1 spondylolisthesis: report of three cases and a review of the literature. Eur Spine J. 1999;8(4):290-5.

2. Magerl F, Aebi M, Gertzbein SD, Harms J, Nazarian S. A comprehensive classification of thoracic and lumbar injuries. Eur Spine J. 1994;3(4):184-201.

3. Barquet A, Menendez J, Dubra A, Masliah R, Pereyra D. Anterolateral dislocation of the lumbosacral junction. Can Assoc Radiol J. 1993;44(2):129-32.

4. Deniz FE, Zileli M, Cağli S, Kanyilmaz H. Traumatic L4-L5 spondylolisthesis: case report. Eur Spine J. 2008:17(Suppl 2):S232-5.

5. Krbec M, Hraběta P. Unilateral isolated dislocation at the lumbosacral junction: lateral flexion-distraction as a major vector in the mechanism of injury: case report and trauma mechanism analysis. Eur Spine J. 2011:20(Suppl 2):S166-71

6. Maynard FM Jr, Bracken MB, Creasey G, Ditunno JF Jr, Donovan WH, Ducker TB, et al. International Standards for Neurological and Functional Classification of Spinal Cord Injury. American Spinal Injury Association. Spinal Cord. 1997;35(5):266-74.

7. Vialle R, Charosky S, Rillardon L, Levassor N, Court C. Traumatic dislocation of the lumbosacral junction diagnosis, anatomical classification and surgical strategy. Injury. 2007;38(2):169-81.
8. Verlaan JJ, Oner FC, Dhert WJ, Verbout AJ. Traumatic lumbosacral dislocation: case report. Spine (Phila Pa 1976). 2001;26(17):1942-4.

9. Steinitz DK, Alexander DI, Leighton RK, O'Sullivan JJ. Late displacement of a fracture dislocation at the lumbosacral junction. A case study. Spine (Phila Pa 1976). 1997;22(9):1024-7.

10. Aihara T, Takahashi $\mathrm{K}$, Yamagata $\mathrm{M}$, Moriya $\mathrm{H}$. Fracture-dislocation of the fifth lumbar vertebra. A new classification. J Bone Joint Surg Br. 1998;80(5):840-5.

11. La Rosa G, Conti A, Cardali S, Cacciola F, Tomasello F. Does early decompression improve neurological outcome of spinal cord injured patients? Appraisal of the literature using a meta-analytical approach. Spinal Cord. 200442(9):503-12

12. Lim CT, Hee HT, Liu G. Traumatic spondylolisthesis of the lumbar spine: a report of three cases. J Orthop Surg (Hong Kong). 2009:17(3):361-5.

13. Dimar JR 2nd, Glassman SD, Raque GH, Zhang YP, Shields CB. The influence of spinal canal narrowing and timing of decompression on neurologic recovery after spinal cord contusion in a rat model. Spine (Phila Pa 1976). 1999;24(16):1623-33.

14. Carlson GD, Minato Y, Okada A, Gorden CD, Warden KE, Barbeau JM, et al. Early time-dependent decompression for spinal cord injury: vascular mechanisms of recovery. $J$ Neurotrauma. 1997;14(12):951-62 